p-ISSN: $2338-4794$

e-ISSN: 2579-7476

Vol.9. No. 1 Januari-April 2021

\title{
PENGARUH INOVASI PRODUK DAN ORIENTASI PASAR TERHADAP KEUNGGULAN BERSAING CELANA MEREK JEANS DI JAKARTA
}

\author{
Iwan Kurniawan Subagja *) \\ *) Dosen Program Studi Manajemen FE UNKRIS \\ Kampus Unkris Jatiwaringin PO BOX 7774/Jat Cm Jakarta \\ Email : iwankurniawan@unkris.ac.id
}

\begin{abstract}
This study aims to analyze the effect of product innovation and market orientation on competitive advantage on Jeans brands in Kebayoran Lama, South Jakarta. This study used survey research type with a sampling method saturated with the number of respondents as many as 30 respondents. Data analysis used multiple linear regression. The results showed that there was a significant influence between product innovation and market orientation on the competitive advantage of jeans brand in Kebayoran Lama Jakarta. Product innovation is something that can be seen as a functional advancement of a product that can take the product one step further than competitors' products. Likewise, market orientation can find out the needs and desires of consumers, so that it can make a competitive advantage over the products being marketed.
\end{abstract}

Keywords: Innovation, market orientation and competitive advantage

\section{PENDAHULUAN}

Sejarah jeans berasal dari bahan denim yang dibuat pertama kali untuk para pekerja kasar atau buruh pekerja oleh Jacob Da Vis, Cavin Rogers Levin Strauss pada tahun 1873 dan mulai menjadi kebudayaan Amerika yang digunakan pada buruh untuk bekerja. Menyebarnya tentang jeans semakin terlihat pada tahun 1950-an dimana sudah menjadi dari sebuah pakaian yang dijadikan trend bagi anak-anak muda untuk bergaya causal. Sehingga muncul berbagai brand yang memproduksi celana ini, berbagai merk jeans antara lain adalah Levi's, Lee dan Wrangler. Sejak itulah Jeans menjadi sebuah bagian dari fashion hingga sekarang dan banyak brand yang mulai mengeluarkan produk Jeans masingmasing serta berbagai model jeans.

Dalam melakukan kegiatan seharihari, kita menggunakan pakaian yang sesuai dengan kegiatan yang kita lakukan masing-masing. Mulai dari bergaya formal sampe casual, sesuai dengan gaya hidup kepribadian masing-masing. Namun, kita harus meninjau kembali kegunaan dasar dari pakaian itu, yaitu untuk melindungi kita dan menutup tubuh kita sebagai manusia dan memang sudah menjadi pokok.

Indonesia merupakan salah satu Negara yang memiliki populasi terbesar keempat di dunia dan terkenal sebagai Negara dengan masyarakatnya yang konsumtif. Maksud dari pernyataan tersebut adalah bahwa masyarakat Indonesia mempunyai kebiasaan membeli sesuatu tanpa melihat status kebutuhan, melainkan untuk menyenangkan hati, sebagai fashion, dan menjadikan belanja sebagai suatu kegiatan rekreasi.

Melihat sudah banyaknya perusahaan barang dan jasa yang berdiri dan bersaing di pasar lokal maupun pasar global, maka banyak strategi yang dilakukan oleh sebuah organisasi untuk 
mencapai targetnya. Oleh sebab itu, sejak pemerintah Indonesia membuka perijinan membuka usaha, banyak perusahaan dan investor asing membuka usaha dan menanam saham di Indonesia karena laju pertumbuhan penduduk yang meningkat dan konsumen di Indonesia terkenal dengan sifat "konsumtif". Hal ini sangat menguntungkan pihak perusahaan atau pengusaha kecil menengah karena di Indonesia mereka bisa mendapatkan penghasilan yang besar sehingga banyak perusahaan dan para usaha kecil menengah bersaing di pasar untuk mendapatkan hati dan perhatian konsumen. Sehubungan dengan perkembangan jaman yang semakin maju dan semakin modern pakaian menjadi suatu hal yang harus dikembangkan yang disebut sebagai fashion. Dalam konteks ini gaya hidup terutama para pengguna celana jeans yang terus up to date.

Namun permasalahan yang timbul adalah perilaku konsumen yang bersifat dinamis, yang artinya susah ditebak atau dinamakan tentang keinginan dan kebutuhan mereka dalam memilih barang dan jasa (Supranto, 2011). Sehingga gaya hidup seperti ini apa yang masyarakat inginkan dan butuhkan sebagai konsumen dan pengaruh dalam pengambilan keputusan mereka dalam membeli celana jeans. Oleh karena itu peneliti ingin mengetahui dengan jelas tentang seberapa besar pengaruh inovasi produk dan orientasi pasar untuk mendapatkan keunggulan bersaing terhadap para pesaing pengusaha lokal maupun pengusaha asing, seperti yang di kutip di atas bahwa permasalahan yang timbul adalah perilaku para konsumen yang bersifat dinamis, yang artinya susah di tebak dan rasa keinginannya, kebutuhan mereka akan fashion untuk memilih-milih barang. Maka para pengusaha celana jeans harus memikirkan apa yang konsumen inginkan agar kebutuhan mereka dapat terpenuhi. Penelitian ini merupakan penelitian replikasi, dimana peneliti meneruskan dari penelitian sebelumnya, hanya saja dalam penelitian ini objek yang diteliti berbeda dengan penelitian sebelumnya.

\section{LANDASAN TEORI}

\section{Inovasi Produk}

Menurut Kotler dan Keller (2009) inovasi adalah produk, jasa, ide dan persepsi yang baru dari seseorang. Sedangkan menurut Bronson (1998) inovasi produk bukan sekedar ide-ide bagus, namun merupakan kombinasi dari ide-ide bagus, staf yang termotivasi dan pemahaman naluri dari apa yang diinginkan konsumen. Sedangkan menurut Trott (2008) mengatakan inovasi adalah manajemen dari semua aktivitas yang berhubungan dengan penciptaan ide, pengembangan teknologi, manufaktur dan pemasaran suatu produk atau proses manufaktur atau peralatan baru (atau perbaikan).

Definisi mengenai inovasi produk menurut Myers dan Marquis dalam Kotler (2010) menyatakan bahwa inovasi produk adalah gabungan dari berbagai macam proses yang saling mempengaruhi antara yang satu dengan yang lain. Jadi inovasi bukanlah konsep dari suatu ide baru, penemuan baru atau juga bukan merupakan suatu perkembangan darisuatu pasar yang baru saja, tetapi inovasi merupakan gambaran dari semua prosesproses tersebut.

Charles et al. (2002) menyatakan bahwa inovasi merupakan bagian dari kerangka kerja yang menghubungkan aspek budaya perusahaan dengan kemampuan berinovasi serta meningkatkan kinerja perusahaan melalui keputusan membeli konsumen. Dari pemikiran di atas dengan adanya inovasi produk yang dilakukan perusahaan, diharapkan dapat meningkatkan keputusan membeli. Hal tersebut juga didukung oleh Kotabe (2012) yang menunjukkan bahwa semakin tinggi 
inovasi produk yang dilakukan perusahaan maka akan semakin tinggi kinerja perusahaan.

Dalam persaingan global, perusahaan harus dapat memodifikasi produknya untuk menambah nilai dari produk yang dihasilkannya dan harus dapat memenuhi kebutuhan dan selera konsumen. Nilai tambah dari produk yang dihasilkan dapat berupa desain/model dari produk yang dihasilkan dan pelayanan dari produk yang dijual. Berkaitan dengan uraian di atas, dapat disimpulkan bahwa inovasi produk adalah gambaran dari berbagai proses mulai dari konsep suatu ide baru, penemuan baru dan suatu perkembangan dari suatu pasar yang baru yang saling mempengaruhi antara yang satu dengan yang lain.

Indikator inovasi terdiri dari inovasi produk, inovasi proses dan inovasi administrasi (Kotler dan Keller, 2009). Inovasi produk didefinisikan sebagai produk atau jasa baru yang diperkenalkan ke pasar untuk memenuhi kebutuhan pasar. Lebih lanjut dapat didefinisikan sebagai proses memperkenalkan teknologi baru untuk digunakan. Hasil dari proses ini berupa pengenalan barang dan jasa baru yang dapat digunakan untuk meningkatkan keuntungan perusahaan.

Inovasi proses adalah suatu elemen baru yang diperkenalkan dalam operasi produk dan jasa dalam perusahaan, seperti materi bahan baku, spesifikasi tugas, mekanisme kerja dan informasi, maupun peralatan yang digunakan untuk memproduksi produk atau jasa. Inovasi administrasi sangat berkaitan dengan perubahan dalam metode operasi bisnis yang dapat memanfaatkan perubahan tersebut secara efektif dalam struktur dan kebijaksanaan organisasi, metode kerja, dan prosedur lainnya untuk memproduksi, membiayai, dan memasarkan produk atau jasa. Inovasi administrasi turut melibatkan perubahan yang berpengaruh terhadap kebijakan-kebijakan organisasi, alokasi sumber daya, dan faktor-faktor lain yang berkaitan dengan struktur sosial organisasi yang secara tidak lengsung berkaitan dengan kegiatan dasar organisasi.

\section{Orientasi Pasar}

Menurut Cravens dan Peircy (2006) menyatakan bahwa ada dua pendekatan yang dapat dilakukan untuk berorientasi pasar, yaitu pendekatan market driven dan pendekatan driving market. Market driven adalah merujuk pada orientasi bisnis yang berdasarkan pada pemahaman dan reaksi terhadap pilihan-pilihan dan perilaku pemain distruktur yang ada. Strategi tradisional berfokus pada konsumen dimana diasumsikan bahwa konsumen mengetahui apa yang mereka inginkan. Sedangkan pendekatan driving market mengimplikasikan pengaruh terhadap struktur pasar atau perilaku pasar, dengan tujuan meningkatkan posisi persaingan. Baik pendekatan market driven dan driving market, sama-sama berfokus pada konsumen, pesaing, dan kondisi pasar secara umum.

Definisi orientasi pasar menurut Tjiptono dan Chandra (2005) adalah pelanggan tidak selalu tahu apa yang mereka inginkan atau ingin dan tidak tahu bahwa mereka tidak mengetahui hal ini. Orientasi pasar menurut Kohli dan Jaworski (1993) adalah orientasi pasar yang di pilih dan bukan nya orientasi pasar atas dasar pertimbangan tertentu. Yang di definisikan menjadi tiga bagian yaitu: 1). Pengumpulan intelejen pasar yang artinya memantau dan menganalisis faktor-faktor yang mempengaruhi kebutuhan dan preferensi konsumen, baik dalam konteks saat ini maupun masa mendatang. 2). Penyebarluasan intelejen pasar adalah intelejen pasar dikomunikasikan dan sebarluaskan kepada semua departemen dan individu relevan dalam organisasi. 3). Responsifitas atas intelejen pasar, yaitu tindakan yang di ambil untuk merespon intelejen pasar yang telah dinkumpulkan dan disebarluaskan secara internal. 
Lamb et al. dalam Tjiptono dan Chandra (2012) juga mengemukakan bahwa orientasi pasar sebagai suatu konsep pemasaran meliputi tiga hal: 1). Fokus pada kemauan dan keinginan konsumen, sehingga organisasi dapat membedakan produknya dengan produk yang ditawarkan oleh pesaing.

2).

Mengintegrasikan seluruh aktivitas organisasi termasuk di dalamnya produksi untuk memuaskan kebutuhan konsumen. 3). Pencapaian tujuan jangka panjang organisasi dengan memuaskan kebutuhan dan keinginan konsumen secara hukum, serta bertanggung jawab atas semua kebijakan tentang konsumennya.

$$
\text { Narver dan Slater }
$$
mendefinisikan orientasi pasar sebagai "budaya bisnis" yang mampu secara efektif dan efisien menciptakan perilaku karyawan sedemikian rupa sehingga menunjang upaya penciptaan nilai superior bagi para pelanggan. Narver dan Slater (1990) mendefinisikan tiga komponen orientasi pasar yaitu: 1). Orientasi pelanggan, yaitu pemahaman yang memadai atas pembeli. 2). Orientasi pesaing, adalah perusahaan memahami keunggulan dan kelemahan jangka pendek serta kapabilitas dan strategi jangka panjang para pesaing saat ini dan pesaing potensial. 3). Koordinasi antar fungsi adalah sebagai pemanfaatan sumber daya perusahaan secara terkoordinasi dalam rangka menciptakan nilai superior bagi para pelanggan sasaran.

Bahwa orientasi pasar adalah suatu konsep multidimensional yang dapat dirumuskan melalui konsep: orientasi pelanggan, orientasi pesaing, koordinasi antarfungsi, dan pembelajaran pada pelanggan.

Indikator orientasi pasar menurut Tjiptono, Gregorius, Adriana (2008) untuk digunakan sebagai penelitian ini adalah: 1). Orientasi Pelanggan merupakan pemahaman yang memadai atas pembeli sasaranagar mampu menciptakan nilai superior bagi mereka secara berkesinambungan. 2). Orientasi Pesaing mencakup bahwa perusahaan harus memahami keunggulan dan kelemahan jangka pendek serta kapabilitas dan strategi jangka panjang para pesaing utama saat ini dan pesaing potensial. 3). Koordinasi antar fungsi mencakup pemanfaatan sumber daya perusahaan secara terkoordinasi dalam rangka menciptakan nilai superior bagi para pelanggan sasaran.

\section{Keunggulan Bersaing}

Tujuan pengembangan strategi dan taktik adalah agar perusahaan mampu bersaing dalam setiap keadaan, terutama pada saat kondisi ekonomi dan politik yang kurang menguntungkan. Untuk itu perusahaan harus memiliki keunggulan bersaing. Menurut Kotler (2010), pengertian keunggulan bersaing yaitu: keunggulan atas pesaing yang didapatkan dengan menyampaikan nilai pelanggan yang lebih besar, melalui harga yang lebih murah atau dengan menyediakan lebih banyak manfaat yang sesuai dengan penetapan harga yang lebih tinggi.

Perusahaan yang bersaing dalam pasar sasaran yang sama selalu akan berbeda dalam tujuan dan sumber dayanya. Ada perusahaan berukuran besar, ada pula yang kecil. Ada yang mempunyai banyak sumber daya, yang lainnya kesulitan dana. Ada yang sudah lama berdiri dan mantap, yang lainnya baru dan belum berpengalaman. Ada yang berusaha keras mencari pertumbuhan pangsa pasar yang cepat, yang lainnya mencari laba jangka panjang. Selanjutnya perusahaan dapat menempati posisi bersaing yang berbeda dipasaran.

Beberapa strategi yang sering dianggap popular dan cukup memadai dalam menciptakan keunggulan bersaing Craven, (2006), yaitu: 1). Differentiation; berkinerja tinggi, kualitas, prestasi, memiliki keistimewahan yang unik, pelayanan termasuk layanan purna jual baik, dan terandalkan. 2). Overall cost 
leadership; market share tinggi, unggul dalam akses raw materials, kelengkapan pabrikasi yang bagus, tidak selalu berasosiasi dengan harga yang rendah. 3). Focus strategi; memiliki target market yang khusus, product line terbatas. 4). Pre emptive move; saluran distribusi intensive, promosi tinggi. 5). Sinergy competitive advantage; system distribusi, brand name, pengukuran biaya dan investasi.

Keunggulan bersaing merupakan hasil dari implementasi strategi yang memanfaatkan berbagai sumber daya yang dimiliki perusahaan. (Dewi, 2006). Berdasarkan hal-hal diatas peneliti mendefinisikan keunggulan bersaing sebagai strategi benefit dari perusahaan yang melakukan kerja sama untuk menciptakan keunggulan bersaing yang lebih efektif dalam pasarnya.

Dalam penelitian yang telah dilakukan Dewi (2006) ada tiga indikator yang digunakan untuk mengukur keunggulan bersaing adalah: 1). Keunikan produk adalah keunikan yang dimiliki oleh produk yang dihasilkan perusahaan sehingga membedakannya dari produk pesaing atau produk umum di pasaran. Sebagai sebuah terobosan yang dihasilkan perusahaan dalam menuangkan hasil ide-ide atau gagasan sehingga menciptakan sesuatu yang berbeda atau unik dari yang lain (pesaing) sehingga mampu memiliki daya tarik bagi pelanggan. 2). Kualitas produk adalah kualitas dari produk yang berhasil diciptakan oleh perusahaan. Pintar dalam memilih bahan baku yang bermutu tinggi, sehingga menghasilkan produk yang berkualitas atau lebih dibandingkan pesaing. 3). Harga bersaing adalah kemampuan perusahaan untuk menghasilkan produk dengan harga yang mampu bersaing di pasaran. Dengan terciptanya suatu produk yang unik dan berkualitas, perusahaan harus bisa menyesuaikan harga supaya harga tersebut sesuai dengan daya beli pelanggan (terjangkau) dalam kata lain tidak membebankan pelanggan, menciptakan pemikiran-pemikiran baru, gagasan-gagasan baru dan menawarkan produk yang inovatif serta peningkatan pelayanan yang memuaskan pelanggan.

\section{METODE PENELITIAN}

\section{Rancangan Penelitian}

Penelitian ini merupakan penelitiaan untuk menganalisis kausalitas antara inovasi produk, orientasi pasar dan keunggulan bersaing. Responden penelitian ini adalah para pedagang celana jeans di Kelurahan Grogol Selatan Kecamatan Kebayoran Lama Kota Jakarta Selatan. Analisis data yang di gunakan adalah analisis deskriptif, regresi linear berganda. Teknik pengumpulan data menggunakan simple random sampling.

\section{Kerangka Konseptual}

Kerangka konsep gunanya untuk menghubungkan atau menjelaskan secara panjang lebar tentang suatu topik yang akan dibahas. Kerangka ini didapatkan dari konsep ilmu atau teori yang dipakai sebagai landasan penelitian yang didapatkan pada tinjauan pustaka atau merupakan ringkasan dari tinjauan pustaka yang dihubungkan dengan garis sesuai variabel yang diteliti. Kerangka konseptual diharapkan akan memberikan gambaran dan mengarahkan asumsi mengenai variabel - variabel yang akan diteliti. 


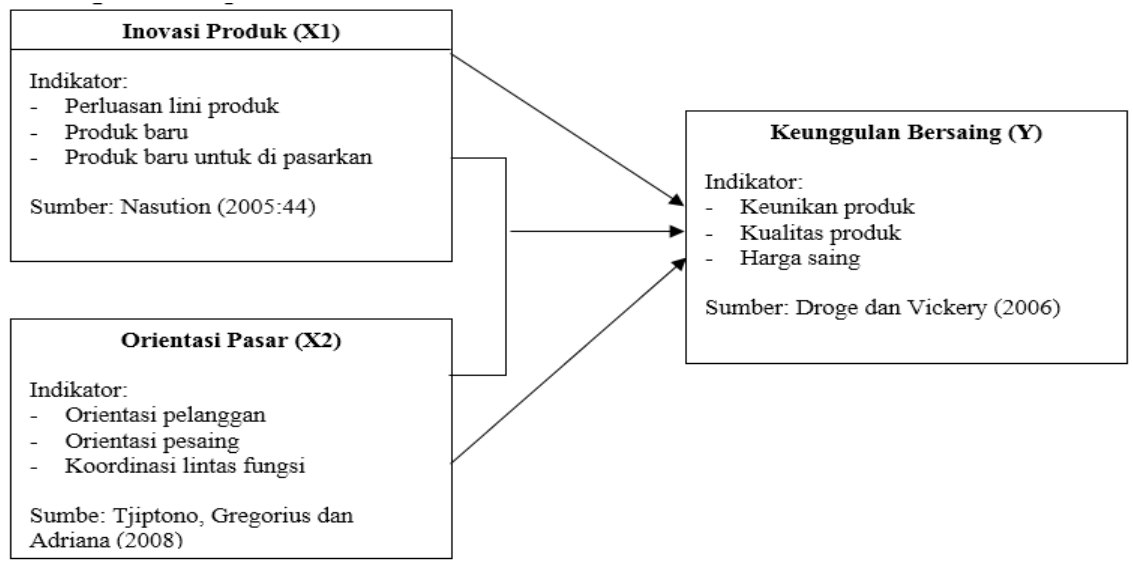

\section{Gambar 1. Kerangka Konseptual}

\section{Populasi dan Sampel}

Populasi ialah gabungan dari seluruh elemen yang berbentuk peristiwa, hal, atau orang yang memiliki karakteristik yang serupa yang menjadi pusat semesta penelitian (Ferdinand, 2006). Populasi dari penelitian ini adalah para pedagang celana jeans yang berada di daerah Kelurahan Grogol Selatan, baik industri kecil maupun menengah sebanyak 30 UMKM.

Sampel adalah sebagian dari populasi, terdiri dari beberapa anggota populasi. Ferdinand (2006). Sampel adalah bagian dari jumlah dan karakteristik yang dimiliki oleh populasi tersebut. penelitian dengan mengambil sampel berdasarkan ciri, sifat-sifat atau karakteristik tertentu. Penelitian ini menggunakan tipe penelitian survei dengan metode pengambilan sampel jenuh dengan jumlah responden sebanyak 30 pedagang UMKM celana Jeans. Metode analisis data menggunakan regresi linear sederhana dan berganda

\section{HASIL PENELITIAN DAN PEMBAHASAN}

\section{Uji Kualitas Data}

\section{Uji Reliabilitas}

Uji reliabilitas adalah alat ukur suatu kuesioner yang merupakan indikator dari variabel atau konstruk. Suatu kuesioner dapat dikatakan reliable atau handal jika jawaban seseorang terhadap pernyataan adalah konsisten atau stabil dari waktu ke waktu. Suatu konstruk dikatakan reliable apabila memberikan nilai Cronbach's Alpha $\geq 0,60$. Sedangkan jika sebaliknya data tersebut dikatakan tidak reliabel (Ghozali, 2005). Hasil perhitungan reliabilitas pada variabel inovasi produk sebesar 0,707. Hal ini menunjukkan Cronbach's Alpha 0,707 $\geq 0,60$. Dapat disimpulkan bahwa pernyataanpernyataan dalam variabel inovasi produk adalah reliabel, artinya bahwa hasil pengukuran variabel inovasi produk adalah konsisten.

Begitu juga dengan variabel orientasi pasar menunjukkan Cronbach's Alpha 0,911 $\geq 0,60$. Dapat disimpulkan bahwa pernyataan-pernyataan dalam variabel orientasi pasar adalah reliabel, artinya bahwa hasil pengukuran variabel orientasi pasar adalah konsisten.

Hasil uji reliabilitas pada variabel keunggulan bersaing diperoleh Cronbach's Alpha 0,940 $\geq 0,60$. Dapat disimpulkan bahwa pernyataanpernyataan dalam variabel keunggulan bersaing adalah reliabel, artinya bahwa hasil pengukuran variabel keunggulan bersaing adalah konsisten. 


\section{Uji Validitas}

Validitas adalah ketepatan atau kecermatan suatu instrumen dalam pengukuran. Validitas digunakan untuk mengetahui kesamaan antara data yang terkumpul dengan data yang sesungguhnya terjadi pada proyek yang diteliti, sehingga dapat diperoleh data yang valid. Pada program SPSS teknik pengujian yang sering digunakan dalam penelitian untuk uji validitas adalah menggunakan korelasi Bivariate Pearson (Pearson Product Moment) dan Corrected
Item-Total Correlation (Sulistyo, 2010). Uji validitas yang dilakukan dalam penelitian ini yaitu dengan membandingkan nilai $r_{\text {hitung }}$ dengan $r_{\text {tabel }}$ untuk df $=\mathrm{n}-\mathrm{k}-1$. Dalam penelitian ini $\mathrm{df}$ $=78-2-1$ atau $\mathrm{df}=75$ dengan $\alpha 0,05$ didapat $r_{\text {tabel }}$ sebesar 0,227 Jika $r_{\text {hitung }}>$ $\mathrm{r}_{\text {tabel }}$ berarti pernyataan tersebut dikatakan valid. Hasil uji validitas untuk $\mathrm{r}_{\text {hitung }}$ (per item) dapat dilihat dalam hasil output SPSS pada pada kolom Correctedd ItemTotal Correlation seperti yang disajikan sebagai berikut:

Tabel 1. Uji Validitas Variabel Inovasi Produk (X1)

\begin{tabular}{llccc}
\hline \multicolumn{1}{c}{ Butir pernyataan } & $\begin{array}{c}\text { Corrected } \\
\text { Item-Total } \\
\text { Correlation }\end{array}$ & $\begin{array}{c}\text { R- } \\
\text { tabel }\end{array}$ & Keterangan \\
\hline $\begin{array}{l}\text { Mengambangkan produk dengan cara } \\
\text { membuat produk baru selain celana jeans. }\end{array}$ & 0.231 & 0.227 & Valid \\
\hline $\begin{array}{l}\text { Membuat produk yang sama dengan } \\
\text { perusahaan lain sebagai suatu strategi } \\
\text { persaingan. }\end{array}$ & 0.69 & 0.227 & Valid \\
\hline $\begin{array}{l}\text { Menciptakan produk baru atau design } \\
\text { terbaru untuk celana jeans. }\end{array}$ & 0.73 & 0.227 & Valid \\
\hline $\begin{array}{l}\text { Banyak menciptakan produk baru yang } \\
\text { menjadi unggulan dalam persaingan pasar. }\end{array}$ & 0.486 & 0.227 & Valid \\
\hline $\begin{array}{l}\text { Selalu aktif dan update dalam } \\
\text { perkembangan untuk design celana jeans. }\end{array}$ & 0.546 & 0.227 & Valid \\
$\begin{array}{l}\text { Terus menciptakan produk baru atau design } \\
\text { terbaru untuk celana jeans untuk memikat } \\
\text { para konsumen. }\end{array}$ & 0.757 & 0.227 & Valid \\
\hline
\end{tabular}

Berdasarkan Tabel 1, pada kolom Correctedd Item Total Statistic ( $\mathrm{r}$ hitung) untuk masing-masing item atau butir pernyataan nilainya lebih besar dari $r$ tabel
0.230 , sehingga dapat disimpulkan bahwa 6 pernyataan untuk variabel inovasi produk adalah valid.

Tabel 2. Uji Validitas Variabel Orientasi Pasar (X2)

\begin{tabular}{lcccc}
\hline \multicolumn{1}{c}{ Butir Pernyataan } & $\begin{array}{c}\text { Corrected } \\
\text { Item-Total } \\
\text { Correlation }\end{array}$ & $\begin{array}{c}\text { R- } \\
\text { tabel }\end{array}$ & Keterangan \\
\hline $\begin{array}{l}\text { Mempunyai kemampuan yang lebih dari } \\
\text { perusahaan lain dalam memenuhi kebutuhan } \\
\text { pasar dalam menghasilkan produk yang tepat } \\
\text { untuk kebutuhan konsumen. }\end{array}$ & 0.856 & 0.227 & Valid \\
\hline $\begin{array}{l}\text { Menggunakan teknik penjualan yang agresif } \\
\text { dalam penjualan sehingga akan mendatangkan }\end{array}$ & 0.625 & 0.227 & Valid \\
\hline
\end{tabular}




\begin{tabular}{|c|c|c|c|}
\hline Butir Pernyataan & $\begin{array}{l}\text { Corrected } \\
\text { Item-Total } \\
\text { Correlation }\end{array}$ & $\begin{array}{c}\text { R- } \\
\text { tabel }\end{array}$ & Keterangan \\
\hline \multicolumn{4}{|l|}{$\begin{array}{l}\text { keuntungan yang tinggi pula dengan tidak } \\
\text { membuat sulit tenaga penjualnya dalam strategi } \\
\text { yang dipilih perusahaan sehingga penjualan } \\
\text { sesuai dengan yang diharapan perusahaan. }\end{array}$} \\
\hline $\begin{array}{l}\text { Sangat memahami para pesaing dan fokus pada } \\
\text { konsumen sehingga dapat memberikan nilai } \\
\text { yang terbaik untuk para konsumen. }\end{array}$ & 0.774 & 0.227 & Valid \\
\hline $\begin{array}{l}\text { Sangat memahami keinginan pasar atau apa } \\
\text { yang di inginkan para konsumen dalam } \\
\text { memutuskan pembelian celana jeans. }\end{array}$ & 0.625 & 0.227 & Valid \\
\hline $\begin{array}{l}\text { Bukan saja melakukan tehknik penjualan yang } \\
\text { agresif,tetapi di dukung juga dengan kwalitas } \\
\text { produk,harga,jaminan } \quad \text { asuransi dalam } \\
\text { pengiriman dan promo. }\end{array}$ & 0.774 & 0.227 & Valid \\
\hline $\begin{array}{l}\text { Cepat dan tanggap dalam merespon para } \\
\text { konsumen baik dalam keluhan ataupun dalam } \\
\text { pertanyaan seputar produk. }\end{array}$ & 0.856 & 0.227 & Valid \\
\hline
\end{tabular}

Berdasarkan Tabel 2, pada kolom Correctedd Item Total Statistic ( $\mathrm{r}$ hitung) untuk masing-masing item atau butir pernyataan nilainya lebih besar dari $\mathrm{r}_{\text {tabel }}$
0.235, sehingga dapat disimpukan bahwa 6 pernyataan untuk variabel orientasi pasar adalah valid

Tabel 3. Uji Validitas Variabel Keunggulan Bersaing (Y)

Butir pernyataan

\section{Corrected}

Item-Total

Correlation

R-
tabel

\begin{tabular}{|c|c|c|c|}
\hline $\begin{array}{l}\text { Perusahaan saya memiliki keunikan produk } \\
\text { yang tidak dimiliki perusahaan lain sehingga } \\
\text { mampu memiliki daya tarik bagi pelanggan. }\end{array}$ & 0.780 & 0.227 & Valid \\
\hline $\begin{array}{l}\text { Perusahaan saya berhasil menciptakan } \\
\text { produk yang bermutu tinggi sehingga } \\
\text { menghasilkan produk yang berkualitas atau } \\
\text { lebih dibandingkan perusahaan lain }\end{array}$ & 0.843 & 0.227 & Valid \\
\hline $\begin{array}{l}\text { Perusahaan saya mampu menghasilkan } \\
\text { produk dengan harga yang dapat bersaing di } \\
\text { pasaran dengan tetap unik dan } \\
\text { berkualitas,sehingga tidak membebankan } \\
\text { para pelanggan untuk membelinya. }\end{array}$ & 0.780 & 0.227 & Valid \\
\hline $\begin{array}{l}\text { Dalam memenuhi kebutuhan para } \\
\text { pelanggan,maka kami selalu memproduksi } \\
\text { barang yang kami anggap sedang ramai di } \\
\text { pasaran dengan jumlah yang sesuai untuk } \\
\text { penjualan dan stock }\end{array}$ & 0.836 & 0.227 & Valid \\
\hline
\end{tabular}




\begin{tabular}{lccc}
\hline \multicolumn{1}{c}{ Butir pernyataan } & $\begin{array}{c}\text { Corrected } \\
\text { Item-Total } \\
\text { Correlation }\end{array}$ & $\begin{array}{c}\text { R- } \\
\text { tabel }\end{array}$ & Keterangan \\
\hline $\begin{array}{l}\text { Perusahan saya mempunyai banyak pilihan } \\
\text { produk dan harga yang berpariasi untuk } \\
\text { memenuhi kebutuhan para konsumen yang } \\
\text { sesuai dengan pangsa pasar mreka masing- } \\
\text { masing }\end{array}$ & 0.843 & 0.227 & Valid \\
\hline $\begin{array}{l}\text { Perusahaan saya juga bersedia mengerjakan } \\
\text { pemesanan yang sesuai dengan keinginan } \\
\text { pembeli yang ingin memakai model sendiri } \\
\text { dan merk sendiri }\end{array}$ & 0.843 & 0.227 & Valid \\
\hline
\end{tabular}

Berdasarkan Tabel 3, pada kolom Correctedd Item Total Statistic (r hitung) untuk masing-masing item atau butir pernyataan nilainya lebih besar dari $r$ tabel
0.235 , sehingga dapat disimpukan bahwa 6 pernyataan untuk variabel keunggulan bersaing adalah valid.

\section{Analisis regresi linear sederhana}

Tabel 4: Pengaruh Inovasi Produk terhadap Keuanggulan Bersaing

\begin{tabular}{lccccc}
\hline \multirow{2}{*}{ Variabel } & $\begin{array}{c}\text { R } \\
\text { Square }\end{array}$ & Konstanta & $\begin{array}{c}\text { Koefisien } \\
\text { Regresi }\end{array}$ & Sig & $\boldsymbol{\alpha}$ \\
\hline Inovasi_Produk & 0,979 & - & 0,950 & 0,000 & 0.05 \\
\hline Pengujian Signifikan & & & & \\
\hline $\begin{array}{l}\text { Keterangan: Variabel Keuanggulan Bersaing } \\
\text { Sumber: data diolah 2020 }\end{array}$
\end{tabular}

Berdasarkan Tabel 4, hasil analisis diketahui nilai koefesien determinasi $\left(\mathrm{R}^{2}\right)$ sebesar 0.979 atau $97.9 \%$ hal ini menunjukkan bahwa kontribusi inovasi produk sebesar $97.9 \%$ terhadap keunggulan besaing, sedangkan sisanya $2.1 \%$ di sumbangkan oleh faktor lain seperti kualitas produk dan lainnya.
Berdasarkan hasil analisis, nilai koefisien regresi inovasi produk bertanda positif dan signifikan. Koefisien regresi inovasi poduk sebesar 0,950 yang artinya jika inovasi produk mengalami peningkatan 1 kali maka keunggulan besaing akan mengalami kenaikan sebesar 0,950 kali atau sebaliknya.

Tabel 5: Pengaruh Orientasi Pasar terhadap Keuanggulan Bersaing

\begin{tabular}{|c|c|c|c|c|c|}
\hline \multirow[b]{2}{*}{ Variabel } & \multicolumn{5}{|c|}{ Parameter } \\
\hline & $\begin{array}{c}\mathbf{R} \\
\text { Square }\end{array}$ & Konstanta & $\begin{array}{c}\text { Koefisien } \\
\text { Regresi }\end{array}$ & Sig & $\alpha$ \\
\hline Orientasi_Pasar & 0,382 & - & 0,429 & 0,000 & 0.05 \\
\hline
\end{tabular}

\section{Pengujian Signifikan}

Keterangan: Variabel Keuanggulan Bersaing

Sumber: data diolah 2020

Berdasarkan Tabel 5, hasil analisis diketahui nilai koefesian determinasi $\left(\mathrm{R}^{2}\right)$ sebesar 0,382 atau $38,2 \%$ hal ini menandakan bahwa orientasi pasar memberikan sumbangan sebesar $38,2 \%$ pada keunggulan bersaing sedangkan 
sisanya $61,8 \%$ disumbangkan oleh faktor lain seperti harga dan sebagainya. Berdasarkan hasil analisis, diketahui nilai koefisien regresi orientasi pasar bertanda positif dan signifikan. Koefisien regrasi orientasi pasar sebesar 0,429 yang artinya jika orientasi pasar mengalami perbaikan 1 kali maka keunggulan bersaing akan mengalami kenaikan sebesar 0,429 kali atau sebaliknya.

\section{Analisis regresi linear berganda}

Tabel 6: Pengaruh Inovasi Produk dan Orientasi Pasar Terhadap Keuanggulan Bersaing

\begin{tabular}{lccccc}
\hline \multirow{2}{*}{ Variabel } & $\begin{array}{c}\text { R } \\
\text { Square }\end{array}$ & Konstanta & $\begin{array}{c}\text { Koefisien } \\
\text { Regresi }\end{array}$ & Sig. & $\boldsymbol{\alpha}$ \\
\hline Inovasi_Produk & 0,616 & - & 0,416 & 0,000 & 0,005 \\
Orientasi_Pasar & & & 0,351 & 0,000 & \\
\hline Pengujian Signifikan & & & & & \\
\hline F hitung > F tabel = 77,647 & & & & \\
\hline Keterangan: Variabel Keuanggulan Bersaing \\
Sumber: data diolah 2020
\end{tabular}

Berdasarkan Tabel 6, hasil analisis diperoleh nilai $\mathrm{F}$ hitung sebesar 77,647 artinya secara bersama-sama inovasi produk dan orientasi pasar berpengaruh positif dan signifikan terhadap keunggulan bersaing. Nilai koefisien determinasi $\left(R^{2}\right)$ sebesar 0,616 artinya kontribusi inovasi produk dan orientasi pasar terhadap keunggulan bersaing sebesar $61,6 \%$ sedangkan sisanya sebesar $38,4 \%$ di sumbangkan oleh faktor lain seperti harga, promosi dan sebagainya.

Berdasarkan hasil analisis diperoleh nilai koefisien regresi inovasi produk bertanda positif dan signifikan. Koefisien regresi inovasi produk sebesar 0,416 artinya jika inovasi produk meningkat satu kali, maka keunggulan bersaing akan meningkat sebesar 0,416 kali dengan asumsi inovasi produk tetap atau tidak berubah. Koefisien regresi orientasi pasar sebesar 0,351 artinya jika orientasi pasar mengalami perbaikan satu kali, maka keunggulan bersaing akan meningkat sebesar 0,351 kali dengan asumsi orientasi pasar tetap atau tidak berubah.

\section{Pembahasan}

Pengaruh Inovasi Produk Berpengaruh Secara Signifikan Terhadap Keunggulan Bersaing

Hasil pengujian hipotesis menunjukkan bahwa inovasi produk berpengaruh secara signifikan terhadap keunggulan bersaing. Inovasi produk yang memiliki arti inovasi produk bukan sekedar ide-ide bagus, namun merupakan kombinasi dari ide-ide bagus, staff yang termotivasi dan pemahaman naluri dari apa yang diinginkan konsumen atau gambaran dari berbagai proses mulai dari konsep suatu ide baru, penemuan baru dan suatu perkembangan dari suatu pasar yang baru yang saling mempengaruhi antara yang satu dengan yang lain yang terdiri dari perluasan lini, produk baru dan produk benar-benar baru. Sehingga inovasi produk merupakan sesuatu yang dapat dilihat sebagai kemajuan fungsional produk yang dapat membawa produk selangkah lebih maju dibandingkan dengan produk pesaing. Hasil penelitian ini konsisten dengan penelitian yang dilakukan oleh Dewi (2006) dimana hasil 
penelitian inovasi produk berpengaruh signifikan terhadap keunggulan bersaing.

\section{Pengaruh Orientasi Pasar Berpengaruh Secara Signifikan Terhadap Keunggulan Bersaing}

Hasil pengujian hipotesis ini menunjukkan bahwa orientasipasar berpengaruh terhadap keunggulan bersaing. Orientasi pasar adalah suatu konsep multidimensional yang dapat dirumuskan melalui konsep orientasi pelanggan, orientasi pesaing, koordinasi antarfungsi, dan pembelajaran pada pelanggan dengan manfaat yaitu, Dapat membantu perusahaan dalam memproduksi produk atau jasa yang sesuai dengan yang dipersepsikan oleh pelanggan, membantu memproduksi secara lebih efisien dibandingkan para pesaing, dapat menjelaskan perbedaanperbadaan kinerja yang dicapai oleh perusahaan dan dapat mengarahkan perusahaan pada competitive advantage yang dapat dipertahankan melalui aktivitas-aktivitas internal, seperti investasi ulang, ambiguitas kasual (lebih mampu mengenal kemampuan diri dengan lebih baik) dan melakukan adaptasi orientasi pasar (adaptation of more maeket oriented) dan aktivitas-aktivitas eksternal, seperti adaptasi dengan perubahan, amniguitas ekternal, intangibility, kecepatan mobilitas, kompleksitas social, efisiensi missal, dan peningkatan efektinitas sejalan dengan waktu serta pengetahuan prosedural. Hasil penelitian ini konsisten dengan penelitian yang dilakukan oleh Dewi (2006) dimana hasil penelitian orientasi pasar berpengaruh signifikan terhadap keunggulan bersaing.

\section{Pengaruh Inovasi Produk dan \\ Orientasi Pasar secara Bersama-sama \\ Berpengaruh Secara Signifikan \\ Terhadap Keunggulan Bersaing}

Hasil penelitian ini menunjukan bahwa inovasi produk dan orientasi pasar secara bersama-sama memiliki pengaruh yang signifikan terhadap keunggulan bersaing. Artinya, inovasi produk dan orientasi pasar secara bersama-sama memiliki dampak pada peningkatan keunggulan bersaing. Dalam rangka meningkatkan keunggulan bersaing, inovasi produk dan orientasi pasar sangat berperan penting dalam suatu perusahaan untuk mencapai keunggulan bersaingnya terhadap para pesaing dan untuk meningkatkan penjualan serta brand suatu perusahaan. Hasil penelitian ini konsisten dengan penelitian yang dilakukan oleh Dewi (2006) bahwa orientasi pasar dan inovasi produk secara simultan berpengaruh terhadap keunggulan bersaing.

\section{KESIMPULAN DAN SARAN}

\section{Kesimpulan}

Berdasarkan hasil penelitian pembahasan mengenai pengaruh inovasi produk dan orientasi pasar terhadap keunggulan bersaing pada usaha kecil dan menengah celana jeans di kelurahan Kebayoran Lama, maka dapat ditarik kesimpulan sebagai berikut: 1). Inovasi produk memiliki pengaruh yang signifikan terhadap keunggulan bersaing dengan tingkat signifikan. Gambaran dari berbagai proses mulai dari konsep suatu ide baru, penemuan baru dan suatu perkembangan dari suatu pasar yang baru yang saling mempengaruhi antara yang satu dengan yang lain yang terdiri dari perluasan lini, produk baru dan produk benar-benar baru. Sehingga inovasi produk merupakan sesuatu yang dapat dilihat sebagai kemajuan fungsional produk yang dapat membawa produk selangkah lebih maju dibandingkan dengan produk pesaing. 2). Orientasi pasar memiliki pengaruh yang signifikan terhadap inovasi produk dengan tingkat signifikan. Artinya orientasi pasar 
memiliki beberapa manfaat yaitu, dapat membantu perusahaan dalam memproduksi produk atau jasa yang sesuai dengan yang dipersepsikan oleh pelanggan, membantu memproduksi secara lebih efisien dibandingkan para pesaing, dapat menjelaskan perbedaanperbedaan kinerja yang dicapai oleh perusahaan dan dapat mengarahkan perusahaan pada competitive advantage yang dapat dipertahankan melalui aktivitas-aktivitas internal, seperti investasi ulang, ambiguitas kasual (lebih mampu mengenal kemampuan diri dengan lebih baik) dan melakukan adaptasi orientasi pasar (adaptation of more maeket oriented) dan aktivitas-aktivitas eksternal, seperti adaptasi dengan perubahan, amniguitas ekternal, intangibility, kecepatan mobilitas, kompleksitas sosial, efisiensi missal, dan peningkatan efektinitas sejalan dengan waktu serta pengetahuan prosedural. 3). Hasil penelitian ini menunjukkan bahwa inovasi produk dan orientasi pasar secara bersama-sama berpengaruh terhadap keunggulan bersaing dengan tingkat signifikan dan sisanya dipengaruhi oleh faktor-faktor lain.

\section{Saran}

1. Penelitian lebih lanjut disarankan untuk menambahkan variabel-variabel yang berpengaruh terhadap keunggulan bersaing yang berkelanjutan, kinerja pemasaran, orientasi sosial, compliance dan koordinasi antar fungsi.

2. Penelitian lebih lanjut diharapkan dapat memperluas daerah survey, tidak hanya di Kebayoran Lama saja sehingga hasil penelitian lebih mungkin untuk disimpulkan lebih umum atau luas.

3. Penelitian selanjutnya disarankan untuk mendapatkan data berupa wawancara dari beberapa pengusaha yang berada di luar Kebayoran Lama yang menjadi responden penelitian agar bisa mendapatkan data yang lebih nyata bisa keluar dari pertanyaanpertanyaan kuesioner yang mungkin yang lebih sempit atau kurang menggambarkan keadaan yang sesungguhnya.

\section{DAFTAR PUSTAKA}

Bronson, Richard, dan Gabriel B. Costa. 2006. Differential Equation Third Edition. McGraw - Hill: United State of Amerika.

Charles W. Lamb, Joseph F. Hair, Carl Mc Daniel. 2002. Pemasaran. Edisi Pertama. Jakarta: Salemba Empat.

Craven, David W \& Nigel F Priecy. 2006. Strategic Marketing, International Edition, McGraw - Hill.

Dewi. 2006. Analisis Pengaruh Orientasi Pasar dan Inovasi Produk Terhadap Keunggulan Bersaing Untuk Meningkatkan Kinerja Pemasaran.

Ferdinand, Augusty. 2006. Metode Penelitian Manajemen. Semarang: Badan Penerbit Universitas Diponegoro.

Ghozali, Imam. 2005. Aplikasi Analisis Multivariate dengan SPSS. Semarang: Badan Penerbit UNDIP.

Kohli, Ajay K., dan Bernard, J. Jaworski. 1993. Market Orientation: The Construct, Research Propositions, and Managerial Implications. Journal of Marketing. Vol.54, p. 118.

Kotabe, Masaaki and Kristian Helsen. 2012. Global Marketing Management. John Wiley \& Sons

Kotler, Philip. 2010. Marketing Management Analysis, Planning, Implementation, and Control, 12th Ed. Englewood Cliff, NJ. New Jersey: Prentice-Hall, Inc.

Kotler, Philip dan Kevin Lane Keller. 2009. Manajemen Pemasaran. Edisi 13 Jilid Satu. Jakarta: Erlangga.

Never, J.C., \& Slater, S.F. 1990. "The Effect of Market Orientation on 
Business Profitability", Journal of Marketing.

Sulistyo, Basuki. 2010. Metode Penelitian. Jakarta: Penaku.

Supranto, J. 2011. Pengukuran Tingkat Kepuasan Pelanggan Untuk Menaikkan Pangsa Pasar, Cetakan Keempat. Jakarta: Penerbit PT Rineka Cipta.
Tjiptono, Fandy dan Chandra. 2012. Pemasaran strategik. Yogyakarta: Penerbit ANDI

Tjiptono, Fandy., Chandra, Gregorius dan Adriana, Dadi. 2008. Pemasaran Strategik. Yogyakarta: Andi

Trott. 2008. Innovation Product Management and new Product development. England, Prence Hall. 